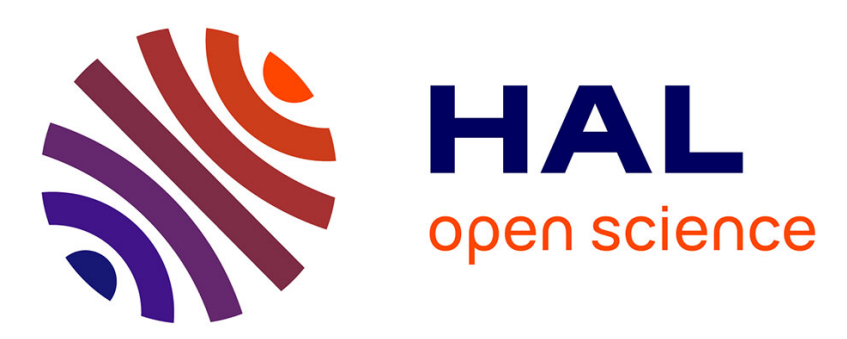

\title{
Major constituent order, information packaging and narrative structure in two Middle French texts.
}

\author{
Claude Muller
}

\section{To cite this version:}

Claude Muller. Major constituent order, information packaging and narrative structure in two Middle French texts.. Andreas Dufter, Daniel Jacob. Focus and background in Romance Languages, John Benjamins, pp.239-279, 2009, Studies in Language Companion Series 112. halshs-00989455

\section{HAL Id: halshs-00989455 \\ https://shs.hal.science/halshs-00989455}

Submitted on 11 May 2014

HAL is a multi-disciplinary open access archive for the deposit and dissemination of scientific research documents, whether they are published or not. The documents may come from teaching and research institutions in France or abroad, or from public or private research centers.
L'archive ouverte pluridisciplinaire HAL, est destinée au dépôt et à la diffusion de documents scientifiques de niveau recherche, publiés ou non, émanant des établissements d'enseignement et de recherche français ou étrangers, des laboratoires publics ou privés. 
Major Constituent Order, Information Packaging, and Narrative Structure in two Middle French Texts

\author{
Claude Muller \\ (Bordeaux-3 \& CNRS: UMR CLLE-ERSS) \\ Claude.Muller@u-bordeaux3.fr \\ claude.muller31@wanadoo.fr
}

Published in:

Focus and Background in Romance Languages

[Studies in Language Companion Series],

Andreas Dufter \& Daniel Jacob (eds),

Amsterdam: John Benjamins (2009).

p. $239-279$. 


\title{
Major Constituent Order, Information Packaging, and Narrative Structure in two Middle French Texts
}

\author{
Claude Muller \\ (University Bordeaux-3 \& CNRS: UMR CLLE-ERSS)
}

\begin{abstract}
Middle French (comprising the fourteenth and fifteenth centuries) offers significant variations in word order, particularly for subject noun phrases. As an intermediate period between Old French and Modern French, Middle French may have had competing structural patterns, which would explain variations in word order. We put forward the hypothesis that the analysis of information packaging and narrative structuring can help to understand such variations. Our investigation underlines the major role of communicative parameters such as focalization, either for informative or for pragmatic reasons, but also as givenness vs. newness in word order choices. The distribution of subject noun phrases before or after the tensed verb - a major problem in the syntax of Middle French - also appears to be linked to communicative parameters involving discourse organization in narrative texts. The pre-verbal position is preferably used for established thematic subjects within a narrative sequence, while a post-verbal position is used for either known, not fully thematic subjects, or entirely new thematic subjects at the beginning of a narrative sequence.
\end{abstract}

\section{Introduction}

This paper provides an investigation of Middle French word order based on the analysis of two contemporaneous narrative texts, both written at the beginning of the fifteenth century. The syntax of Middle French is to some extent at an intermediate position, between Old French verb second and Modern French subject-verb-object (SVO) declarative constituent order. Middle French syntax is of particular interest to historical linguists as it represents the last period with salient differences from present-day varieties, while Classical French, the period following Middle French, already exhibits roughly the same word order possibilities as Modern French. At the same time, Middle French has not been as thoroughly studied as Old French, ${ }^{1}$ a period for which syntactic descriptions such as Skårup (1975) are of great interest (see also Vance 1997, Buridant 2000). Indeed, Middle French has often been passed off as a period of transition between Old and Modern French, as such many irregularities have been put down to the resulting competition between syntactic structures inherited from Old French and innovations anticipating Modern French. Of course, it is possible to consider the variant constituent orderings of Middle French as being merely a random reflection of ongoing change in basic sentence structures. However, it is also conceivable that the observed variability is systematically linked to discourse parameters. In this paper, we shall suppose that informative and communicative parameters (including narrative choices), in addition to the traditional functional and structural factors, can at least partly explain some areas of variability which earlier descriptions simply dismissed as inconsistencies typical of such an interim phase of grammatical evolution. ${ }^{2}$ Thus, information structure and discourse organization could be the principal forces at work in these changing of word order patterns.

In section 1, we present our corpus of Middle French historical texts (1.1), a sketch of Old French syntax (1.2), followed by a discussion of the functional and structural parameters which are relevant for Middle French word order (1.3). In section 2, we introduce the information functions used in our analysis (2.1), and we examine how word order variations can affect information structure in the case of subject inversion (2.2). In section 3, we 
examine a selection of features displayed by the information structure and narrative organization in the chosen Middle French texts. Sections 4 and 5 link the subject ordering with information structure: section 4 covers post-verbal subjects, section 5, pre-verbal subjects. Furthermore, in this section we will also defend the hypothesis that narrative structuring rather than information structure at the sentence level may help to explain the choice of pre-verbal subjects in the context of competing grammars for our texts. Section 6 extends this analysis to the less frequent construction of pre-verbal object noun phrases, which have a defined semantic profile in independent clauses, confirming early observations concerning pre-verbal subjects. Finally, our conclusions are presented in section 7.

\section{Corpus and structural parameters}

\subsection{The corpus analysed}

Our examination is based on a grammatical analysis of two extracts of historical texts in prose, which date from the beginning of the fifteenth century and are considered to be representative of the written French of the period: ${ }^{3}$ one excerpt of Froissart's Chroniques and one from the Journal d'un bourgeois de Paris (JBP). We categorize the individual constituents according to their grammatical function; thus, noun phrases are classified as subject, direct object, dative, non-dative indirect object and, in some cases, as attributive. Among the adverbial phrases, locative and temporal adverbials are singled out because they are of crucial importance for the information structure. Adjective phrases are not specified when adnominal, whereas predicative adjective phrases are included in the study. Subject personal pronouns are separately coded. Verbal components are classified as V (tensed verbs), Pp (past participles) and Inf (infinitives). By definition, every sentence includes a V component. ${ }^{4}$ The most frequent coordinating connectors or relators are separately coded, such as, e.g., et 'and', mais 'but', car 'as, because', or 'now, in fact' or item 'ditto'. Complex conjunctions are represented by the single label Conj, whereas in complement clauses and in relative clauses, the subordinating item is not separately tagged. Our labelled corpus comprises more than two thousand clauses from the Journal d'un bourgeois de Paris (written between 1405 and 1418) and about five hundred from Froissart (a text which refers back to events that took place in the year 1389 but was probably written at the beginning of the fifteenth century). These data allow us to examine in detail a major element of variation in the structure of the clause, namely the position of the subject, both for nominal and for overt pronominal subject constituents.

\subsection{Old French syntax}

Old French (until 1300) is characterized by a systematic difference in major constituent order between independent and subordinate clauses. In independent clauses, the regular order is of the verb second type with an initial constituent X, which may be the subject of the clause or, just as well, a non-subject constituent, such as an object complement or adverbial. Overt subjects need to be positioned postverbally whenever the pre-verbal X position is filled by a non-subject constituent in declarative sentences. In such cases of syntactically triggered subject-verb inversion, the subject is normally placed immediately after the tensed verb. In information structural terms, the constituent $\mathrm{X}$ can be a topic which features in the clause (often but not always memorized by the speaker), a focus, with a contrastive meaning (it is $X$, not $Y$, that...), or an initial word without any informative content, such as an expletive subject il (see Vance 1997: 40 for an example from the thirteenth century). 
Subordinate clauses do not generally have the trigger position and often begin with the subject. Given the long period of Old French, it is also conceivable that these clauses followed different structural patterns. It is sometimes supposed that in the period preceding the written use of Old French subordinate clauses could have had subject-object-verb (SOV) structure, as is the case in the first extant French text, the Strasbourg Oaths (Serments de Strasbourg) (Skårup 1975: 502-503). Such a verb final structure is sometimes found in relative clauses, even in late Old French or Middle French. However, the majority of subordinate clauses attest an SVO-type structure, with a small number of exceptions following the constituent order of independent clauses, in which a non-subject constituent between the subordinator and the finite verb triggers subject-verb inversion. Some authors therefore suggest that Old French was an asymmetrical verb second language, in which the verb second rule only holds true in independent clauses (Vance 1997: 30), and perhaps in some restricted cases of complement clauses, when the complement clause is governed by verbs such as verba dicendi: complement clauses of predicates such as dire 'say' sometimes exhibit subject-verb inversion with pronominal subjects (Vance 1997: 143). The opposite point of view, according to which Old French is a symmetrical verb second language (Lemieux \& Dupuis 1995), claims that a verb second rule operated in subordinate as well as in independent clauses and argues in favour of an identical position of the triggering first item inside the clause (in the generative descriptions, an IP position instead of the commonly accepted CP position). It should be noted that Vance (1997), while defending an asymmetrical description, also provides a different analysis for independent clauses of the SVX type in thirteenth-century Old French. According to Vance, the XVS type is amenable to a standard verb second analysis, with $\mathrm{V}$ in $\mathrm{C}_{0} .{ }^{5}$ However, when the first term is the subject, Vance assumes an IP structure with the verb in $\mathrm{I}_{0}$ and the subject in the specifier of IP, as is commonly postulated for Modern French.

\subsection{Sentence structures in Middle French}

\subsubsection{Verb second sentences}

In contrast to Old French, Middle French lacks a clear-cut syntactic differentiation between independent and subordinate clauses. What remains from Old French is the possibility of verb second constructions with post-verbal subjects. In independent clauses, many sentences continue to have the subject constituent immediately in the post-verbal position, even in cases where a past participle (1) or a direct object (2) follows:

(1) Pourquoy sont ces huy fermez? [JBP §797]

why are these doors locked-up

'Why is this door locked up?' (transl. Shirley 1968: 340)

(2) Item, le $X X V^{e}$ jour dudit moys de septembre, emmenerent les gens d'armes les prinsonniers [...] [JBP §809]

item the 25th day of.the.aforesaid month of September, took the people.of.weapons the prisoners

'On the 25th of September the soldiers took [...] those prisoners [...]. (transl. Shirley 1968: 345)

Furthermore, it is possible to find an object noun phrase before the tensed verb, as in (3):

(3) [...] et les gembes qu'on pendoit aux portes mangerent ilz en saillant [...] [JBP §315] and the legs which one hung at.the doors ate they byjumping 
'They ate legs, too, that were hung up over gates, by jumping up at them [...]' (transl. Shirley 1968: 162)

In embedded clauses, a focussed object following a conjunction or a wh-word may also precede the verb:

(4) Quand ce virent les Angloys, ilz s'en allerent pillant [...] [JBP §257]

when this saw the English they went-away plundering

'Seeing this, the English went their way, stealing [...]' (transl. Shirley 1968: 141)

\subsubsection{The type $X S V$}

We have come across a substantial number of clauses in which the subject precedes the verb, either as the only pre-verbal constituent or after initial non-subject constituents, as in (5). In the latter case, this XSV structure competes with the XVS type. ${ }^{6}$ At any rate, no verb second constraint seems to be operative any more:

(5) Item, le jeudi ensuivant, ung autre nommé Colin de Brie, escuier, fut prins oudit lieu comme devant est dit, et prins au Palays, trayné comme Simonnet devant dit, et couppé sa teste es halles [...] [JBP §67]

item the Thursday following an other named Colinde Brie esquire was caught at.the.aforementioned place as afore is said and put in.the Palais dragged as Simonnet afore said and cut his head in.theHalles

'Next Thursday, another man, called Colin de Brie, esquire, captured at the same place as above, was taken from the Palais, dragged to the Halles like Simon, and there beheaded.' (transl. Shirley 1968: 73)

If one accepts Vance's analysis of the SVX type, which she describes as IP structures rather than CP structures (Vance 1997: 39), sentences such as (5) illustrate the generalization of older non-verb-second constructions already present in Old French, albeit in restricted contexts.

In fifteenth-century Middle French, the order subject-verb, although statistically predominant in the totality of clauses examined, is found to be less frequent than the reverse ordering in independent clauses. In our corpus, Froissart's Chroniques has post-verbal subjects in independent clauses 58\% of the time, the Journal d'un Bourgeois de Paris, 54\%. In subordinate clauses, by contrast, the proportions of post-verbal subjects are $6 \%$ and $18 \%$, respectively.

\subsubsection{The pre-verbal sequence of connectors and adverbs}

In contrast to Old French, Middle French quite readily permits more than just one pre-verbal constituent. In particular, it even allows for sequences of connectors. The sequence of constituents preceding the finite verb is usually made up of two distinct categories, both able to trigger the post-verbal positioning of the subject. In the Journal d'un Bourgeois de Paris, the propositional content is explicitly linked to the preceding context by coordinating conjunctions such as et 'and', mais 'but', or conjunctive adverbs like si or item. These connectors may be followed by adverbials, which typically act as frame-setters for the eventuality described by the verb phrase, cf. (6). In many cases, these frame-setting adverbials can be considered scenic topics.

(6) Item, le $V^{e}$ jour de may, fut le bastart de Vauru trainé parmy toute la ville de Meaulx, et puis la teste coppée, et son corps pendu à ung arbre. [JBP §343] 
item the 5th day of May was the bastard de Vaurus dragged through all the town of Meaux and then the head cut and his body hung to a tree 'On the fifth day of May the Bastard of Vauru was dragged all over the town of Meaux and then beheaded. His body was hung on a tree.' (transl. Shirley 1968: 172)

While sentences in which an isolated conjunction (particularly et 'and') triggers subject-verb inversion are not completely absent from Old French, they are far more typical of the Middle French period, during which time this type of inversion "takes on new dimensions" (Marchello-Nizia, 1997: 415). ${ }^{7}$ Example (7) from our corpus illustrates this structure:

(7) Et furent tous leurs biens mis en la main du roy. [JBP §72]

and were all their goods put in the hand of.the king

'[...] and all their goods were confiscated by the Crown [...]' (transl. Shirley 1968: 78)

\subsubsection{Pre-verbal object noun phrases and predicative adjective phrases}

In most cases where a sentence has an object noun phrase or a predicative adjective phrase in pre-verbal position, the subject is positioned postverbally. It rarely happens that the pre-verbal sequence hosts an argument XP other than the subject, while this is possible in the case of object noun phrases or predicative adjectives:

(8) $[\ldots]$ et très chier coustoit une ceste lettre $[\ldots][\mathrm{JBP} \S 845]$

and very expensive cost-IMPERF a this letter

'Very dear these letters were.' (transl. Shirley 1968: 356)

Wherever this occurs, the resulting structures belong to one of three different syntactic patterns: (i) the verb second type, as in (9); (ii) the XSV type, as in (10), which has objectsubject-verb ordering (a rare variant), or (iii) the modern type, with a topic left-dislocation structure and a resumptive clause-internal pronoun, as in (11):

(9) [...] car le Chastelet fut eschellé de toutes pars, et descouvert et prins par force, et tous ceulx de dedens mis à l'espée, et la plus grant partie fist on saillir sur les carreaulx, où grant compaignie estoit du peuple qui les occioient sans mercy de plus de cent plaies mortelles [...] [JBP §220]

for the Châtelet was escalated of all sides and destroyed and taken by force and all those of inside put to the sword and the more great part made one come.out on the paving where great company was of.the people who them killedwithout mercy of more of hundred wounds mortal

'[...] the walls were scaled on all sides, the Châtelet opened up and taken, and everyone inside it slaughtered. They made most of them come out on to the paving, where the main body of the mob mercilessly killed each one of them with more than a hundred mortal blows.' (transl. Shirley 1968: 125)

(10) [...] et tant hayoient ceulx qui gouvernoient ceulx qui n'estoient pas de leur bande, qu'ilz proposerent que par toutes les rues ilz les prendroient et tueroient sans mercy, et les femmes ilz noieroient [...] [JBP §189]

and so.much hated those who ruled those who NEG-1 were NEG-2 of their gang that they resolved that through all the streets they them would.take and would.kill without mercy and the women they would.drown 
'[Such was Paris's evil government.] Its rulers so detested all who were not on their side that they resolved to seize and kill them all without mercy in every street; the women they were going to drown.' (transl. Shirley 1968: 111)

(11) Item, la plus grant partie des cappitaines qui estoient dans Paris, on les paioit des advoynes que on avoit amenées à Paris pour estre bien salvement, et avoient congié de prendre ce qu'ilz povoient autour de Paris, à II ou III lieues environ, et ilz ne s'en faignoient pas. [JBP §170]

item the more great part of.the captains who were in Paris one them paid INDEF-ART-PL oats which one had brought to Paris forbe well safely and had permission to take that which they couldaround Paris at two or three leagues about and they NEG-1 REFL of.it deprived NEG-2

'Most of the captains in Paris were paid out of the oats that had been brought into Paris for safety. Also they had permission to take anything they could get, up to two or three leagues around Paris, at which they were in no way backward.' (transl. Shirley 1968: 106)

\subsubsection{An extended verb second type}

A noticeable change observable during Middle French is the increasing cohesiveness of the verbal group. In tensed clauses with compound verb forms, the past participle tends more and more to be placed immediately after the finite auxiliary. Thus, in many sentences with a nonsubject first constituent, or with a sequence of pre-verbal non-subject terms, the subject does not appear in third position, immediately postverbally, but in a position further to the right of the sentence. In this case, the subject follows a complex verbal group, made up of an auxiliary and a past participle or infinitive. Such sentences are often analysed as being different from verb second structures (Vance 1997: 272). For Vance (1997: 349), two competing structural analyses are available for the Middle French type XVS, viz. verb second or the modern Stylistic Inversion type. According to Vance, verb second sentences and sentences showing Stylistic Inversion differ radically in their syntactic structure. However, we have to bear in mind that Vance's discussion is limited to sentences with non-compound verb forms. In our opinion, some sentences of Middle French lend support to another hypothesis, i.e. that a derived verb second type could also apply to compound verb forms, the verbal "zone" being able to receive these compound forms: one could say that the old verb second system is split up into two competing constructions, verb second on the one hand, and a construction whereby one part of the verbal group is located in second position on the other. Examples (12) to (14) illustrate the last option:

(12) Item, the XIX jour de may, jour Sainct Yves, fist mettre le roy le siege devant Creel par le connestable. [JBP §799]

item the 19th day of May day saint Yves made put the king the siege before Creil by the constable

'On 19th May, St. Yves's day, the King had the Constable lay siege to Creil.' (transl. Shirley 1968: 342)

(13) Et furent faiz monseigneur de Berry et monseigneur de Bourbon cappitaines de la ville de Paris [...] [JBP §1]

and were made lord of Berryand lord of Bourbon captains of the town of Paris.

'[...] and my lords of Berry and of Bourbon were made Captains of the town of Paris.' (transl. Shirley 1968: 47) 
(14) [...] et eust esté le roy ars qui ne l'eust mis hors par devers le meilleur. [JBP §108] and would.have been the king burnt who not would.haveput out through into the better '[...] the King himself would have been burned if they had not got him out on the safest side.' (transl. Shirley 1968: 90)

Sentences in which the subject follows a non-finite verb but precedes an object noun phrase (12), a copula complement (13), or another past participle (14) cannot be analysed as showing Stylistic Inversion. Instead, we suppose that the verbal position is occupied by both the auxiliary and one or more non-tensed verbs, independent of the meaning of the individual sentence.

\subsubsection{Pre-verbal pronouns}

Pre-verbal subject pronouns are cliticized on the tensed verb, at least on the surface level; however, in Old French only post-verbal subject pronouns are definitely cliticized (see Skårup 1975). According to Vance (1997: 288), pre-verbal subject pronouns in embedded clauses are encliticized to the complementizer in Old French, but not in Middle French. Except for one single token of $j e$ 'I' in Froissart, subject personal pronouns in Middle French are no longer separated from the tensed verb by lexical material. The only items that may still intervene are clitics expressing negation and non-subject pronominal clitics. The category of clitic subject personal pronouns must include the impersonal on ( $<$ Latin homo 'man.NOM'), which exhibits the same properties as subject clitics derived from Latin pronominal forms. However, it is possible that the pre-verbal subject pronouns are attached to the verb only in terms of phonology, being full arguments in the syntax (Vance 1997: 289). Here, Vance follows the argumentation of Kayne (1984) concerning subject pronouns in Modern French.

\subsubsection{Subordinate clauses}

In subordinate clauses, the predominating structure is the type ConjSVX. Yet some variation is attested, since a non-subject complement can precede the finite verb. Relative clauses may show a somewhat different syntactic organization in that the subject relative qui offers a regular pre-verbal position for a complement (15). Furthermore, the tensed verb is sometimes placed at the end of the clause after a dependent past participle (16), which seems to maintain the archaic SOV pattern described by Skårup (1975: 502).

(15) Si advint par le plaisir Deu que ung mauvais eir corrumpu chut sur le monde, qui plus de cent mil personnes à Paris mit en tel estat qu'ilz perdirent le boire et le manger, le repouser $[\ldots][\mathrm{JBP} \S 93]$

and happened by the pleasure of.God that a bad aircorrupt fell on the worldwhich more of hundred thousand persons at Paris put in such state that they lost the drink and the food the sleep 'And it pleased God that a foul corrupt air should fall upon the world, an air which reduced more than a hundred thousand people in Paris to such a state that they could neither eat, drink, nor sleep [...]' (transl. Shirley 1968: 85)

(16) [...] ils creront en luy et diront que c'est Messias qui promis leur estoit, et l'aoreront comme Dieu. [JBP §865]

they will.believe in him and will.say that it is Messiah who promised them was and him will.worship as God 
'[...] they will believe in him and will say that he is their promised Messiah and will worship him as God.' (transl. Shirley 1968: 362)

\subsubsection{Summary}

The following formula summarizes the general ordering pattern found in Middle French independent declarative clauses:

(connector) (scenic) (C) (S) V (S) (Pp) (S) (Complements) (S) (Additional comments)

Constraint:

At least one of the four pre-verbal positions must be occupied in declarative clauses.

(C) is either an optional nominal complement (contrastively focussed) or an adverbial complement. The subject $\mathrm{S}$ is not obligatory and may occupy several positions; if $\mathrm{S}$ is a personal pronoun, only the positions adjacent to $\mathrm{V}$ are acceptable.

Generative analyses of the last decades have suggested many approaches in order to explain the properties of Middle French. It is generally admitted that Middle French remains a verb second language (Vance 1997: 273), with reanalysis of some structures. Thus, the XVS type in independent clauses can sometimes be reinterpreted according to the pattern of Stylistic Inversion (Vance 1997: 338), in which the finite verb remains in $\mathrm{I}_{0}$ and does not raise to $\mathrm{C}_{0}$. Concerning XVS clauses, we suppose that there are four patterns in Middle French: (i) verb second when the finite verb immediately precedes the subject and when the subject is followed by a past participle or an object noun phrase; (ii) an extended verb second type when the subject follows the finite verb and a non-finite one (infinitive or past participle) but also precedes an object, a predicative adjective, or another past participle; and finally there are the two modern types (iii) Stylistic Inversion and (iv) 'Heavy Inversion' with a 'heavy' clausefinal subject. When the post-verbal subject is a personal pronoun, we suppose that the structure can only be of the verb second type. Consider (17), a sentence which lends itself to an analysis as either verb second or Stylistic Inversion:

(17) Ainsi s'en alla la belle Agnès, le dixiesme jour de may ensuyvant à son peché comme devant. [JBP §884]

so went.away the beautiful Agnès the tenthday of May following to her $\sin$ as before

'Thus Fair Agnes went away, back to her sin as before, on 10th May.' (transl. Shirley 1968: 367)

The structural conditions are met for verb second, but that sentence, with a verb of movement and an emphatic subject, could also be a case of Stylistic Inversion, exactly as in Modern French. In any event, the ordering of major constituents in sentences such as (17) cannot simply be dismissed as a freely available stylistic rearrangement option, but needs to be analysed as a direct reflection of a particular information packaging. Thus, according to Vance (1997: 59), a post-verbal subject in a verb second structure is thematic and known to the speaker, whereas it must be focussed in cases of Stylistic or 'Heavy' Inversion. The modern type SVX, already existent in Old French, was not confined to signalling subject focus according to Vance (1997: 40). Vance observes that an initial subject generally expresses known or presupposed information, but also that "such information is not linked to the discourse in any specific way". However, she does not take into account the "presumed familiarity" of the reader with the semantic content of the subject. In the next section, we will 
clarify our principal communicative and information structural concepts, before applying these parameters to the analysis of Middle French in the remainder of this article.

\section{Communicative parameters}

\subsection{Communicative and information structural concepts}

In this section, we will take stock of the currently accepted information structural concepts that are relevant to the present study.

\subsubsection{The distinction between entirely new and partially known information}

It can be useful to distinguish thetic sentences ('all-new' information) from categorical sentences (of which a part is known). This does not mean that there is no topic in a thetic sentence. Both the topic (locally supporting what is being said) and the discourse topic may introduce new information. The distinction between a completely new topic and a previously introduced one, even in a recurrent mode, is of crucial importance. For example, in the Journal d'un bourgeois de Paris, there are recurrent references to the price of wood or meat, or the rate of coins; in such cases the structure of the sentence could have been influenced by the narrator's feeling that the sentence conveys an additional remark on an old topic, rather than offering completely new information on a new topic (cf. section 5 below).

\subsubsection{Text units}

It is somewhat easier to distinguish the various narrative units within the story, each of them organized with reference to a discourse topic in a sub-story. Such sequences are referred to here as narrative sequences. Note that the position of one sentence, at the beginning or inside a narrative sequence, can also be of importance when trying to explain word order variation.

\subsubsection{Background knowledge}

Besides textually given information, everything concerning both the civilization of the time and its customs must be regarded as given.

\subsubsection{The topic}

In most clauses there is a sentence topic, which is the support of what is said in the comment. The topic can be either known (given) or new: it is essentially the term about which something is said. Krifka's more precise definition - "The entity or set of entities under which the information expressed in the comment constituent should be stored in the Common Ground content" (Krifka 2007: 41) - is interesting in that it does not exclude a possible focalization on a topic or its newness. What is relevant is only the procedure of classification of information under mental headings.

\subsubsection{The comment}

This represents what is said about the topic. When there is more than one term, it is quite probable that one part will be more salient, thus being a focus inside the comment. We must, however, identify a particular case, sometimes difficult to appreciate in Middle French, namely the possibility of side-structure information: additional comments, associations, embellishments (Levelt 1993: 136). Such side-structure must be distinguished from the comment. Usually, such appendices providing side-structure information directly follow the comment. The end of the comment is naturally focussed, this being due to the communicative dynamism: it is a property of an expression that reflects its relative degree of importance in 
comparison with other expressions in the sentence (Firbas 1992; cf. also the review by Chafe 1994). Functional notion partially depends on other semantic or pragmatic features of the expression (a given expression has less communicative dynamism than a new one), but the speaker has a certain degree of freedom in exploiting that property: there is a general tendency to put the major informative constituent at the end of the sentence. Thus, it may be difficult to see the difference between a final term in the comment and in background information. Of course, prosody may help to signal the intended information structure, but of course no prosodic cues are available in the Middle French prose texts under study.

\subsubsection{The focus}

This must be a salient linguistic expression which is considered to be of importance. Following Krifka, we shall suppose the existence of several types of foci, either informative (often in final position) or pragmatic and prosodically marked, probably in front position. É. Kiss (1998) shows that in many languages one must distinguish between an identificational focus and a simple information focus. In the first case, the focus receives a logical rather than a discursive definition: it carries the features of exhaustive and contrastive identification on a previously established discursive set of entities. In medieval French, argument noun phrases in the first position of a sentence can function either as identificational foci or, when no exhaustive interpretation is intended, as contrastive topics. In Middle French, such a fronting of focus constituents is rare, and most focus expressions are informational foci and are positioned at the end of the sentence. But is a focus necessarily contrastive? The matter is discussed by Krifka. Basically, it seems to us that pragmatic foci are not always contrastive. We may note that contrastivity does not entail newness: the focus may be both known and contrastive, just as for discourse topics associated with a new event. The relevance of the contrast must be evaluated in the context: following Chafe, we shall admit that this notion of contrast applies only when there is a limited number of paradigmatic choices available. Another point seems important to us. Chafe suggested, without explicitly committing himself to this idea, that there could be a gradation in focalization. In analysing information structure in our texts, it became clear to us that some constituents which appear to be focussed and could be considered as the most prominent ones within their clause if they had appeared in clause-final position, can be downgraded in terms of focus-background structure by another constituent following it. We must then assume a scale of focality (see 4.2 below).

What, then, are the relations between information structural notions - such as topic, comment, or focus - and grammatical categories? As expected, noun phrases are the best candidates for function of topic or focus, and among them, subjects typically function as informative topics, while objects are canonical targets of default focus. Adverbials have special topical functions, and are also possible foci. Verbs, especially intransitive ones, may also be focussed. Final constituents in apposition or adverbials sometimes need to be analysed within their larger context of occurrence and with recourse to knowledge of the historical background in order to determine whether they are fully informative, and thus potentially focussed, or whether they belong to the side-structure information.

A topic can bear focus features. We shall suppose that this is the case when the topic (in the informative and classificatory meaning given above) is at the same time the outcome of the communicative dynamism and, of course, when it is contrastive. This happens quite often in Middle French in sentences having a final subject. What can then be said about the remainder of the clause? We could suppose that the comment is emptied of its content or we must admit an overlap between topic and comment. Furthermore, the comment sometimes includes a secondary focus. I use the notion of "focussed topic" principally for final subjects, considering that the scenic adverb which most of the time opens the sentence in front position is only a frame-setter, not a participant of the verbal action. 


\subsection{The influence of word order on communicative functions}

We shall consider, as an example, the semantic differences induced in Modern French by nominal subject inversion, i.e., Stylistic Inversion in generative analyses. In Modern French, the default focus is found in final position. Here the verb loses a part of its semantic content and the global meaning can be modified. Compare examples (18a-b):

(18) a. Dans ce bureau, quatre personnes travaillent / travaillent bien.

in this office four persons work / work well

'In this office, four people work / work well.'

$\neq$

b. Dans ce bureau travaillent quatre personnes / travaillent bien quatre personnes. in this office work four persons work well four persons 'Four people are working (well) in this office.'

(Cornish 2001)

In (18a) the focus is on the final verb, as it is the default focus position. The natural interpretation is that the people mentioned are actually carrying out work, which is shown by the evaluative meaning of the adverb bien 'well'. In (18b), the predicate has no such evaluative meaning component, and the sentence takes the 'habitual' meaning (there are four workplaces).

(19) a. Dans l'armoire, les chaussures sont cirées.

in the cupboard the shoes are polished

'In the cupboard, the shoes are polished.'

b. ??Dans l'armoire sont cirées les chaussures.

in the cupboard are polished the shoes

??'The shoes are polished in the cupboard.'

The sentence in (19a) has an evaluative meaning (the shoes are well-polished in an orderly manner), because the final verb is focussed. The sentence in (19b) implies a rather odd interpretation: the polishing of the shoes seems to happen inside the cupboard. No evaluative meaning is present and the predicate denotes an action linked to a place, because no locative meaning is possible. Thus, subject inversion in Modern French is not only a way of achieving focalization of the subject, for it can also affect the semantic interpretation of the entire clause.

If Stylistic Inversion exists in Middle French, as is assumed by Vance (1997: 167), it could yield, in contexts of locative inversion, focus on the subject and a stative interpretation of the verbal predicate. This seems to be the case in examples such as (20):

(20) [...] et là ou long de l'escharfault estoit ordonné le pas du roy Saladin et tous fais de personnages, les crestiens d'une part et les sarazins d'aultre part. [Froissart 351] and there along of the scaffold was arranged the battle of.the king

Saladin and all made of persons the Christians of one side and the Saracens of other side

'[...] and there along the stand was arranged the fight of the king Saladin and all actions of characters, the Christians on one side and the Saracens on the other side.' 
The verb has no evaluative meaning, and the final stress marks focus on the subject. In the same descriptive context, when the verb must be interpreted as an evaluative predicate and the subject is given, the preferred clause type is verb second:

(21) Et jusques à l'eglise Nostre Dame estoient les rues parees. [Froissart 353] and until to the church Notre Dame were the streets decorated 'And until the church Notre-Dame were the streets ornamented.'

In the next section, we shall examine elements in sentence-initial position and strategies of topic change in Middle French.

\section{Discourse organisation in Middle French}

\subsection{Sentence-initial elements and discourse organisation}

As has been observed above, time and place adverbs in first position are scenic topics which are not incompatible with argument noun phrases occurring before the tensed verb. Those elements, scenics as well as connectors, have two quite distinct functions: connectors are discourse links, whereas scenics introduce the frame of the following event. In some cases, the narrative is an immediate continuation of what precedes. In other cases, the connector introduces a new storyline or a new discursive sequence which often spans an entire paragraph. As we will see in section 5, such a structuring into discursive sequences, which is of great importance in a diary like the Journal d'un bourgeois de Paris, can explain, at least in part, some of the variation observed in the positioning of the subject.

Example (6), repeated below as (22), illustrates the relationship between the constituents of a sentence and their communicative functions: ${ }^{8}$

(22) Item, le $V^{e}$ jour de may, fut [le bastart de Vauru] $]_{\mathrm{TOPIC}}$ [trainé parmy toute la ville de Meaulx $]_{\text {COMMENT, et puis }}[\text { la teste }]_{\text {TOPIC }}[\text { coppée }]_{\text {FOCUS, }}$ et $[\text { son corps }]_{\text {TOPIC }}[$ pendu à ung arbre $]_{\text {COMMENT. }}$ [JBP $\left.\S 343\right]$

item the 5th day of May was the bastard de Vaurus dragged through all the town of Meaux and then the head cut and his body hung to a tree 'On the fifth day of May the Bastard of Vauru was dragged all over the town of Meaux and then beheaded. His body was hung on a tree.' (transl. Shirley 1968: 172)

Connector / Scenic / V of the comment / topic / (comment (focus))

Connector/sub-topic / focus

Connector/sub-topic / (comment (focus))

This sentence occurs in a passage that reports the fate of the French loyalist war chiefs in the town of Meaux, which had been taken just before by the English army. The information structure remains identical in the three segments of the sentence, with topics occurring before their comment. The body-parts referred to, which function as sub-topics, are semantically related to the principal topic le bastart de Vauru. A significant feature, compared to Modern French, is the possibility in Middle French to isolate the tensed auxiliary fut from the comment, according to the logic of the verb second clause format. Thus, the end of the clause contains the topic and its comment side by side, with a final focus.

\subsection{Discourse organisation and change of topic}


Within a discourse sequence, sentences following the sequence-initial one are typically combined by means of coordinating conjunctions. In such units of discourse, the initial topic may make way for another one, which is normally closely linked to it, cf. (23):

(23) Et furent sur le point de trois heures après nonne en la place de Sainte Caterine et ja estoient venues [les dames] $]_{\text {TOPIC, }}$ [la roynne de France $]_{\text {TOPIC }}$ toute premiere, et fut amenee jusques à là en ung char couvert moult richement [...] et [les aultres dames et

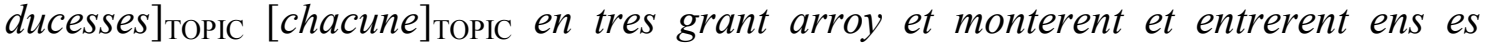
escharfaulz qui ordonnez estoient pour elles. [Froissart 362]

and were on the point of three hours after nun in the place of St. Catherine and already were come the ladies the queen of France all first and was driven until to there in a chariot covered very richly and the other ladies and duchesses each in very great state and went.up and entered in.the scaffolds which prepared were for them

'At three o'clock, [the knights] were in the place de Sainte-Catherine and the ladies had already come, first of all the queen of France, and [the queen] was driven till there in a big chariot covered very richly [...], and the other ladies and duchesses were each one in very rich array and went up and entered in the scaffolds which were organized for them.'

The topic function passes from the knights to the ladies. First, it centres on one of them, the queen, then it returns to the ladies, and is next distributed on "each of them", before coming back to the general set, "the ladies". The changes obey the proximity rule given above: the subject matter is the account of a tournament, and it belongs to the shared knowledge of the time that the principle actors of a tournament, the knights, fight before the very eyes and under the judgment of their ladies. As can be seen in that sentence, topics may be focussed, and a sub-topic is sometimes a specification of a more general one (here, the queen among the ladies), a partition (the other ladies), or a distributive presentation (each one).

In the following example, there is also a change of topic, also associated with a focalization on the new one, but with a gradation: the new focussed topic constituent must be more salient than preceding focus constituents within the sentence:

(24) Ce merquedy arriva à Paris [le conte de Saint Pol] $]_{\mathrm{TOPIC}}$, qui revenoit tout droit d'Angleterre et s'estoit moult hastez pour estre à celle feste [...] Sy fu [le conte de Saint $\mathrm{Pol}]_{\text {TOPIC }}$ le tres bienvenu du roy et de tous les seigneurs, et estoit à celle feste et dalez la roynne de France [sa femme] Tоріс, qi fu moult joieuse de sa venue. [Froissart 363] this Wednesday arrived in Paris the count of St. Pol who came.back all direct from England and REFL was much hasted for be at that party thus was the count of St. Pol the very welcomed of.the king and of all the lords and was at that fair and near the queen of France his wife who was very happy of his coming (lit.) 'This Wednesday arrived in Paris the count de Saint Pol, who came back directly from England, and hurried much in order to be in that feast. The count of Saint Pol was very welcomed by the king and by all the lords, and was at that feast, and near the queen of France was his wife, who was very happy of his coming.'

The initial topic is the discourse referent designated by le conte de Saint Pol, which is also in focus. This discourse referent remains the topic of the relative clause, which is of limited informativity and can be considered an additional, secondary comment. In the second 
sentence, the topic expression is repeated in the typical position of a non-focussed topic. In what follows, in spite of the coordination and the risk of a misinterpretation, the topic changes, or, more precisely, focalizes on a sub-topic, sa femme 'his wife', which must be prosodically more prominent than the double focus immediately before. The end of the sentence, a relative clause, is also an additional comment. As we can see, the change of topic is rather easy and the post-focus position of the last topic turns it into a sort of 'super-focus', which is the culmination point of the whole sentence in terms of its communicative dynamism.

In the next part of this article, we will seek to assess the hypothesis that communicative parameters play a role in the choice of the subject position. To this end, we will examine postverbal subjects in section 4, first in auxiliary-participle constructions and then in single verb clauses, before moving on to pre-verbal subjects in section 5 .

\section{Post-verbal subject position, thematization and focalization}

\subsection{Clauses containing an auxiliary and a past participle}

\subsubsection{The verb-subject-past participle sentence type (VSPp): the subject is mostly an anaphoric, non-focussed topic.}

The linear order verb-subject-past participle is no longer available in Modern French, while it is rather frequent in Middle French. We found 26 VSPp clauses in the Journal d'un bourgeois de Paris and 12 in Froissart (against 68 and 7 of the VPpS type, respectively). In almost all cases of VSPp, the subject is a topic for what follows, and is also a known discourse referent, either anaphoric or inferred from the context. This situation obtains in all 12 cases found in the Froissart text fragment under study, and in 25 out of 26 occurrences of VSPp in the Journal d'un bourgeois de Paris. Two illustrative examples are given in (25) and (26):

(25) [...] et estoit le dit escharfault couvert de draps [...] [Froissart 352] and was the said scaffold covered with cloth ' $[\ldots]$ and the afore-mentioned scaffold was covered with cloth $[\ldots]$ '

(26) Et le XVII jour dudit moys d'octobre, jeudy, fut le dessus-dit grant maistre d'ostel mis en une charrette, vestu de sa livrée [...] et en cel estat mené es halles. [JBP §10] and the 17th day of.the.said month of October Thursday was the abovesaid grand master of household put in a cart dressed of his livery and in this state led to.the halls 'On Thursday 17th October this Grand Master of the Household was put into a cart, wearing his own colours [...] like this taken to the Halles.' (transl. Shirley 1968: 51)

Some subjects belong to a special type: they are formed by, or include, the thematic indefinite pronoun tout 'all, every'. These subjects seem to be focussed:

(27) Ainsi estoit tout gouverné, comme vous avez ouy. [JBP §90]

so was everything ruled as you have heard

'This is how everything was run, as you have heard.' (transl. Shirley 1968: 84)

There are six sentences that display the pattern, including four with the pronoun tout 'all' and two with the determiner, for instance (7), repeated below as (28):

(28) Et furent tous leurs biens mis en la main du roy. [JBP §72] 
and were all their goods put in the hand of.the king '[...] and all their goods were confiscated by the Crown.' (transl. Shirley 1968: 78)

The propositional content of (28) invites the interpretation of the subject being an exhaustive focus. In all other cases, except one, the subject noun phrase has a definite determiner. Only one sentence introduces an entirely new discourse referent in that position, which naturally is expressed by an indefinite noun phrase:

(29) Et à l'entrée de la Villette Sainct Ladre, au bout de devers Paris, furent deux hommes tempestez, dont l'un fut tué tout mort [...] [JBP §8]

and at the entrance of the Villette St.Lazare at.the end of to Paris were two men struck of.them the one was killed all dead

'And at the Paris end of the Villette-St.-Lazare two men were struck; one of them was killed outright [...]' (transl. Shirley 1968: 51)

Even so, the subject remains a topic for what follows. The explanation for that position could be a focalization constraint: the salient information is provided by the past participle; note that placing the subject after the participle would falsely lead to a focus on the subject (particularly on the number): the subject, although new, is not focussed in this example.

\subsubsection{The VPp $(x)$ S type: the final subject is a focussed topic providing new information}

The entire set of $\operatorname{VPp}(\mathrm{x}) \mathrm{S}$ sentences, with a post-verbal subject following the past participle and possibly some other constituents, comprises 95 cases in the Journal d'un bourgeois de Paris. 71 of the subjects in these clauses are foci, whereas only 24 qualify as topics. In Froissart there are only eight instances of $\operatorname{VPp}(x) S$, six or seven of which appear to exhibit subject focus.

In typical constructions (cf. (30)-(34) below), the subject is placed in the final position of the sentence in order to signal the non-canonical focus-background structure, viz. subject focus. Most of these sentence-final subjects are informative proper nouns, or indefinite noun phrases. In the majority of cases, these subjects occur in passive sentences:

(30) Item, le lundi VII jour d'octobre ensuivant, fut prins ung nommé Jehan de Montagu grant maistre d'ostel du roy de France [...] et fut mis en Petit Chastellet. [JBP §9] item the Monday 7th day of October following was taken a named Jean of Montaigu grand master of household of.the king of France and was put in Petit Châtelet

'On Monday 7th October 1409, a man called Jean de Montaigu, Grand Master of the King's Household, was arrested and [...] put into the Petit Châtelet.' (transl. Shirley 1968: 51)

(31) [...] mais par la grace de Dieu ledit Gaucourt et ses gens furent desconffys honteusement; et en furent tuez bien $\mathrm{VI}^{\mathrm{c}}$, et bien cent noyez, et bien cinquante des plus gros prins $[J B P \$ 27]$

but by the grace of God the.said Gaucourt and his people were defeated shamefully and of.them were killedwell 600 and well hundred drowned and well fifty of.the more big taken

'[...] but by God's grace Gaucourt and his men were shamefully defeated. At least six hundred of them were killed and a hundred drowned and fifty of their most important men taken.' (transl. Shirley 1968: 61) 
The quantified expression bien $V I^{c}$, which constitutes the theme or topic in terms of filing providing an address for storing the information provided in the clause, is focussed and occurs after the participle. However, we notice that in the subsequent clauses, which lack a finite verb, quantified expressions of a very similar type precede the participle. In these clauses, it seems that the two expressions - the noun and the participle - are both focussed. Probably, there is a gradation in focalization, with a heightened importance of the constituents that occur in the last position within their clauses. In (32) to (34), however, the relative importance of the post-verbal non-subject constituents is weak, and the position of such adverbial expressions appears to be more variable:

(32) Item, le mardi XXVII jour de septembre, jour Sainct Cosme et Sainct Damien, fut despendu par nuyt du gibet de Paris Jehan de Montagu, jadis grant maistre d'ostel du $\operatorname{roy}[\ldots][J B P \S 57]$

item the Tuesday 27th day of September day St.Cosmas and St.Damian was taken.downat night of.thegallows of Paris Jehande Montagu formerly grand master of household of.theking

'On Tuesday, September 27th, St. Cosmas and St. Damian, the body of of Jean de Montaigu, sometime Grand Master of the King's Household [...] was taken down at night from the gallows [of Paris]' (transl. Shirley 1968: 69)

(33) Et furent en celle année trouvés à Paris en aucuns lieux escorpions que on n'avoit point en ce temps acoustumé à veoir. [JBP §308]

and were in this year found in Paris in some places scorpions which one NEG-1 was NEG-2 in this time used to see

'Scorpions were found this year in some places in Paris, which in those days was very unusual.' (transl. Shirley 1968: 160)

(34) Et furent celle journée à Paris morz à l'espée ou d'aultres armes, en my les rues, sans aucuns qui furent tuez es maisons, cinq cent vingt deux hommes. [JBP §193]

and were that day in Paris killed at the sword ou of other arms in mid the streets without some who were killed in.the houses five hundred twenty two men

'Five hundred and twenty-two men died by the sword or other weapons that day in Paris out in the streets, not counting the ones who were killed inside the houses.' (transl. Shirley 1968: 114)

In (32)-(34), the subject comes after several other major constituents. Such subjects which occur late in their clause are strongly emphasized and tend to be structurally 'heavier' than subjects occurring in earlier subject positions (cf. Vance 1997: 170). In (33), the relative clause that follows the subject is a background comment.

Now, how can we explain the fact that in some of these sentences there are post-verbal subjects which are obviously not focussed, or at least not the most strongly focussed terms? If we admit that informativity tends to increase within sentences from left to right, as claimed by the theory of communicative dynamism, a non-final subject, even when focussed, remains an informationally subordinated expression with respect to what comes after it, and the clausefinal position tends to be prosodically more prominent. Such sentences are of the type VPp(x)SY, with Y as the main focus. In some cases, the subjects following a past participle do not seem to be focussed, as in (35), which could be analysed as a case of what we called an extended verb second structure (see section 1.2.5 above): 
(35) Là lui on coupa la teste, et après fut porté le corps au gibet de Paris, et pendu au plus hault $[\ldots][\mathrm{JBP} \S 10]$

there him-DAT one cut the head and afterwards was taken the body

to.the gallows of Paris and hung at.the more high

'There they cut his head off and afterwards his body was taken to the Paris gallows and hung up as high as it would go [...]' (transl. Shirley 1968: 51)

Yet, in other cases, the subject is obviously informative and is a focussed topic, which in turn may precede an information focus:

(36) Item, les festes de Nouel ensuivant [...] fut fait par le roy le comte d'Alençon duc d'Alençon [...] [JBP §116]

item the holidays of Christmas following was made by the king the count of Alençon duke of Alençon

'Next Christmans [...] the King created the Count of Alençon Duke of Alençon [...]' (transl. Shirley 1968: 92)

(37) [...] et furent aussi criez à prendre petiz moutons d'or pour XVI solz parisis [...] [JBP $\S 158]$

and were also proclaimed to take small moutons of gold for 16 sols

parisis

'Small gold moutons [...] to be reckoned at $16 s[$ ols $]$ p[arisis].' (transl. Shirley 1968: 103)

However, not all clause-final major constituents are necessarily focussed. We must distinguish salient foci, the informationally most prominent part of the comment, from backgrounded information. Consider (38):

(38) Item, le vendredi ensuivant, furent commencées à murer les portes comme autresfoys. [JBP §147]

item the Friday following were begun to block.up the gates as in.the.past 'Next Friday they began blocking the gates up again.' (transl. Shirley 1968: 101)

Here, the underlined adverbial merely provides a supplementary comment, whereas the salient piece of information is the blocking up of the gates. A similar observation can be made for (39):

(39) Item, la vigille Sainct Jehan furent remises les chesnes de fer au boutz des rues de Paris [...] [JBP §209]

item the eve St. John were put.back the chains of iron at.the ends of.the streets of Paris

'On St. John's eve the iron chains were put back across the ends of the streets of Paris.' (transl. Shirley 1968: 121)

As a matter of fact, in those times there were chains in the streets of Paris to close the streets at night. For a fifteenth-century reader, this was common knowledge. Likewise, everybody knew at that time that such chains, which were taken away in war or riot periods, were placed at the ends of the streets. Thus, the last locative marker provides no new information for the coeval reader and must probably be understood as a backgrounded part of the comment rather than as an information focus. 
In some cases, as in (40) below, a sentence-initial global emphasis must be distinguished from information focus at the end. The sentence in (40) follows directly after the listing of the knights who were killed or captured in the defeat of Azincourt:

(40) Oncques, puis que Dieu fut né, ne fut fait telle prinse en France par Sarazins ne par autres [...] [JBP §130]

never since that God was born NEG was made such capture in France by Saracens nor by others

'Never since God was born did anyone, Saracens or any others, do such destruction in France.' (transl. Shirley 1968: 96)

Here there is a sentence-initial focus on the adverbials and an information focus on the passive subject. The constituent par Sarazins ne par autres hardly brings in any new information at all, all the more so since the Saracens are the typical bad guys of the time. Rather, this additional constituent serves as a scalar expression of intensity and constitutes, in a way, an extension of the emphatic beginning of the sentence realized by the focussed scenic. That is, the final constituent achieves a reinforcement of the main information, viz. the extraordinarily large number of people killed or caught in a single battle. In spite of its emphatic character, the end of the sentence is therefore motivated by rhetorical structure rather than by information structure.

Despite the fact that the subject comes after a non-tensed verb, some of these sentences could be seen as cases of an extended verb second construction (where V includes a past participle or an infinitive), especially when the subject is not focussed and when a final term brings the most prominent information, as in (35) above.

\subsection{XV(O)S / XVSO: the main focus comes at the end of the comment}

In other constructions with a single verb and a post-verbal subject, the conclusions are identical: a final subject is the main focus. Conversely, in a VSO sentence, it is the object which is focussed. Consider (41), which is VOS:

(41) Secondement et ou millieu tenoient et adextroient la littiere le duc de Berry et le duc de Bourgoingne. [Froissart 349]

secondly and in.the middle held and escorted the litter the duke of Berry and the duke of Bourgogne

'The duke of Berry and the duke of Bourgogne held and escorted the litter in the middle.'

The reader already knows that the new queen enters Paris in a litter, escorted by princes whose names convey more information than the object la litière. Consequently, these subjects are focussed and placed after the direct object. A similar situation obtains in (42):

(42) Et vindrent ce chastel requerre et assaillir aultres gens [...] [Froissart 357]

and came this castle demand and assault other people

'And other people came in order to demand and to assault this castle.'

Here, too, the final major constituent provides the principal information, viz., that there is another group of people intervening in the tournament. The subject occurs separated from its tensed verb by the infinitive complement, which in turn includes a direct object, resulting in the old object-verb order inherited from Latin and Old French. It should be noted that 
emphatically focussed subjects may occur at a considerable distance from the verb, cf. the identificational focus on the subject in (43):

(43) Et ot le pris des joustes pour le mieulx joustant de tous et qui le plus avoit continué de ceulx de dehors, par l'assentement et jugement des dames et des hiraulx, le roy de France. [Froissart 363]

and had the prize of.the jousts for the best jousting of all and who the most had pursued of those of outside by the assent and judgment of.the ladies and of.the heralds the king of France

'And it is the king of France, for being the best jousting of all, and the man who had at most pursued the fight among those from outside, who received the price of the jousts, by the assent and the judgment of the ladies and the heralds.'

Conversely, subjects occurring before the object in verb-second sentences normally are nonfocussed topics:

(44) Et donnoit ceste fontainne par ses conduis claré et pieument tres bon et par grans rieux. [Froissart 350]

and gave that fountain by its pipes Clairé and Piement very good and through great streams

'And that fountain ran in great streams of Clairé and excellent Piement.'

\subsubsection{Double-focus constructions}

In support of the Chafian idea of focus as a gradual notion, we may cite sentences in which there is both an emphasized topic with contrastive focus and a second focus in the canonical sentence-final position:

(45) Vous devez savoir que le mardy sur le point de xij. heures vindrent les bourgois de Paris environ .xl. tout des plus notables, vestus tous d'un drap, tous paraulx, à l'ostel du roy à Saint Pol et apporterent ce present [...] [Froissart 359]

you must know that the Tuesday at the point of 12 hours came the citizens of Paris about forty all of.the more notable dressed all of a cloth all alike at the hôtel of.the king at Saint Pol and brought this present

(lit.) 'You must know that on Tuesday at twelve o'clock came the burgesses of Paris, about forty of the most notable ones, clothed all of a cloth, each alike, to the hotel of the king at Saint Pol and brought this present.'

The subject of the first embedded clause in (45) is a 'heavy' noun phrase, with two parts, the second one providing both a quantitative specification and a qualitative evaluation. The clause introduced by que thus exhibits subject-verb inversion, which is found only rarely in subordinate clauses. However, the subject is not the unique focus, for the outcome of the sentence is the locative complement à l'ostel du roy à Saint Pol 'at the hotel of the king at Saint Pol' which is placed after the subject. This final focus is the result of the communicative dynamism and thus does not rule out the presence of a focus of another type earlier in the sentence.

There are some cases of variation in constituent order that do not seem to correlate with differences in information structure. The double focalization on a post-verbal subject and on a direct object is not linked to any significant change of meaning. Thus, with the set phrase faire procession 'walk in procession', we find the following two possibilities: 
(46) Le sabmedi ensuivant firent ceulx du Chastellet, tous grans et petiz, procession. [JBP $\S 48]$

the Saturday following made those of.the Châtelet all great and small procession

'Next Saturday all the Châtelet people, great and small, went in procession.' (transl. Shirley 1968: 66)

(47) [...] c'est assavoir, le penultime jour de may oudit an, jour de lundi, firent procession ceulx du Palais de Paris [...] [JBP §29]

it is ascertained the penultimate day of May of.the.said year day of Monday made procession those of.the Palais of Paris

'On Monday, the next to last day of May in the same year, the people of the Palais in Paris [...] went in procession [...]' (transl. Shirley 1968: 62)

It is also possible to find a pre-verbal subject with the same predicate, in spite of the scenic topic at the beginning:

(48) Le mardy derrenier jour de may, oudit an, partie des paroisses de Paris firent procession $[\ldots][J B P \S 30]$

the Tuesday last day of May of.the.said year part of.the parishes of Paris made procession

'On Tuesday, the last day of May in the same year, some of the town's parishes made processions [...]' (transl. Shirley 1968: 62)

These variations do not seem to lead to significant changes in meaning (cf., however, section 6 below on partitives in pre-verbal position). Even a 'heavy' topic may be found between the verb and a final term, as in (49). This linear order is understandable only if this final term also bears focus in spite of being short:

(49) Tretout le temps que le roy fut hors de Paris, firent ceulx de Paris et ceulx des villaiges d'entour procession, comme devant est dit, et alloient chascun jour par ordre en procession aux pellerinaiges de Nostre Dame entour Paris, comme au Blanc-Mesnil [...] [JBP §51]

all the time that the king was outside of Paris made those of Paris and those of.the villages of around procession as afore is said and went each day through order to.the pilgrimages of Our Lady around Paris as at.the Blanc Mesnil

'All the time that the King was away from Paris, the people of Paris and of the surrounding villages made processions, as I have described. Each day they went in procession to one of the places of pilgrimage of Our Lady round about Paris, as for instance to Blanc-Mesnil [...]' (transl. Shirley 1968: 66)

A special type of double-focus sentence is obtained when the information structure links two paradigms, as, for instance, in (50) with a man and a place. We notice that the notion of topic as a label for storing new information may be attributed both to the place and to the man. Thus, the two contrastive foci are equally informative topics, and the ordering can be freely interchanged: 
(50) Et etoit garde de la porte de Sainct-Denis le sire de Gaule, et de celle de Sainct-Martin Louys Bourdon [...] et le duc de Berry gardoit le Temple, Orleans Sainct-Martin des Champs, Arminac l'ostel d'Artois qui estoit le droit chief d'eulx, Alençon Behaigne [...] [JBP §87]

and was guard of the gate of St. Denis the sire of Gaule and of St Martin Louis Bourdon and the duke of Berry guarded the Temple Orleans St. Martin des Champs Armagnac the Hôtel of Artois who was the real head of them Alençon Bohème 'Messire de Gaule was in charge of the Porte St. Denis and Louis Bourdon [...] of the Porte St. Martin. The Duke of Berry was in command of the Temple, Orleans of St.Martin-des-Champs, Armagnac, their real head, of the Hôtel d'Artois, and Alençon of the Hôtel de Bohème [...]' (transl. Shirley 1968: 83)

\section{Pre-verbal subjects: the role of the narrative sequences}

\subsection{Pre-verbal nominal subjects at the beginning of the fifteenth century}

The diachronic evolution towards an almost invariable placement of the subject before the verb is one of the most intensely investigated research topics in historical French syntax. However, published studies on the topic are sometimes difficult to interpret and compare with one another as the statistics provided do not always measure the same categories. ${ }^{9}$ In Middle French, the share of post-verbal nominal subjects remains considerable in independent clauses (more than 50\% in the labelled basis of our study, cf. the table below). ${ }^{10}$ Thus, there are 381 pre-verbal subjects among the 737 subject noun phrases (S) in both the independent and the subordinate clauses in our excerpt of the Journal d'un bourgeois de Paris. In independent clauses, post-verbal subject noun phrases are in the clear majority, with 213 pre-verbal subjects versus 339 occurring after the tensed verb. By contrast, in subordinate clauses the great majority of nominal subjects are pre-verbal; we found 168 pre-verbal subjects against only 17 in post-verbal position. In the Froissart text investigated, there is a total of 208 subject noun phrases (S), 96 of them pre-verbal and 112 following the tensed verb. Again, it is revealing to distinguish between independent and subordinate clauses. In the former class, we have 53 pre-verbal and 108 post-verbal nominal subjects, whereas in subordinate clauses, the proportion is strikingly different: 43 pre-verbal nominal subjects as against only 4 post-verbal ones.

\subsection{The pre-verbal nominal subject: a participant inside a narrative sequence?}

The general preference that appears to hold is that in the absence of a clause-initial nonsubject item that triggers subject-verb inversion, such as a connector or a scenic topic, independent clauses preferably begin with the subject. In Froissart's text, there are 18 occurrences among the 53 pre-verbal subject noun phrases in which the subject is the only pre-verbal constituent. In the remaining 35 cases, however, the clause is headed by an item which might have triggered inversion, but actually fails to do so. Given this, it seems natural to ask what motivates placing the subject preverbally in such clauses.

A detailed examination of this class of clauses suggests two explanations. One explanation, to which we will return below, is simply that since pre-verbal placement is a means of focalizing constituents in general, pre-verbal subject noun phrases following clause-initial non-subject items are focussed as well. However, an explanation along these lines does not seem attractive for the majority of clauses with pre-verbal subjects, since these do not seem to 
bear a special focus interpretation or emphasis, judging by their individual contexts of occurrence. Rather, these pre-verbal subjects are all topics, but of a particular sort: The majority of them designate participants of what could be called a sub-story inside the general story. Crucially, then, these pre-verbal subject noun phrases do not introduce a new participant in a new storyline. Most of the time such subjects are names of known participants, and in some cases these nominal subjects simply denote referents which are known and familiar to the readership of the time. In (51), we find ourselves 'inside' such a narration. Here, within the story about the royal procession going to Notre-Dame, one sentence mentions the bishop of Paris. Even though this figure was not mentioned before, his existence can be inferred from the context:

(51) Et au devant de l'eglise Nostre Dame de Paris, en la place, l'evesque de Paris estoit revestus des armes de Nostre Seigneur et tout le college aussy [...] [Froissart, 354] and at.the before of the church Notre Dame de Paris in the square the bishop of Paris was dressed in.the arms of Our Lord and the whole college too

'And, before the church Notre Dame de Paris, on the square, the bishop of Paris was dressed in Our Lord's arms, and the whole college too.'

It seems, therefore, that the choice between pre-verbal and post-verbal position for a subject noun phrase denoting a familiar referent may be influenced by narrative structure. Inside a narrative sequence, the subject denoting a familiar referent may be placed before the verb, even in clauses in which there are other pre-verbal elements, such as connectors or scenic topics. Similarly, when the referent of a nominal subject has been previously mentioned within the same sub-story, this nominal subject occurs before the verb. Furthermore, it is easy to understand why many non-focussed pre-verbal subjects are the only pre-verbal elements within their clause: within a narrative sequence there is no need for frame-adverbials, nor do connectors seem useful in many cases:

(52) Et quant les dames orent passé le Grant Pont de Paris [...] il estoit ja tart. Car les chevaulx et ceulx qui les dames menoient n'alloient ne n'avoient allé depuis qu'ilz departirent de Saint Denis que le petit pas. Le Grant Pont de Paris estoit tout au long couvert et cellé de blancq et de vert cendal. [Froissart 353]

and when the ladies had passed the Grand Pont de Paris it was already late for the horses and those who the ladies escorted neither went nor had gone since they left of Saint Denis but the small pace the Grand Pont de Paris was all at.the long covered and sealed of white and of green silk 'And when the ladies had crossed over the Grand Pont de Paris, it was already late. For the horses, and those which the ladies escorted, had advanced but at foot's pace since they left from Saint Denis. The Grand Pont of Paris was all along covered and baldachined with white and green silk.'

Among the subjects designating familiar referents, we may include noun phrases with tous, tout 'all'. Even if such noun phrases pick out new discourse referents, they totalize formerly introduced participants and come mostly at the end of a sub-story:

(53) Tous ces chevalliers estoient armez et parez en leurs targes du ray du soleil. [Froissart 362] 
all these knights were armed and decorated in their shield of.the ray of.the sun

'All these knights were armed and decorated on their shields with the sun's ray.'

The same explanation holds true also with indefinites, when they represent a part of a known group or set. Thus, in (54) the reference set is 'the ladies' and is well known. The indefinite determiners realize a partition of that set:

(54) Aucunes dames demourerent au palais et aucunes s'en retournerent à leurs hostelz en la ville [...] [Froissart 358]

some ladies stayed in.the palace and some REFL of.it returned to their hôtels in the town

'Some ladies stayed in the palace, and some others came back to their mansions in the town.'

In such cases, the subject is mostly pre-verbal, even if other elements occur in the pre-verbal part of the clause:

(55) Pareillement aultres bourgois de Paris, tres richement parez [...] vindrent devers la roynne de France [...] [Froissart 360]

in.the.same.way other citizens of Paris very richly dressed came towards the queen of France

'In the same way, other citizens of Paris, very richly dressed came towards the queen of France.'

(56) Et pareillement toutes les aultres dames furent mises hors de leurs littieres [...] [Froissart 354]

and in.the.same.way all the other ladies were put out of their litters

'And in the same way, all the other ladies were got down from their litters.'

Only a handful of sentences with pre-verbal subjects do not contain contextual specifications. As already noted above, the only remaining tokens of pre-verbal nominal subjects in independent clauses appear to be focussed topics occurring inside a narrative sequence. We found three instances of this type in Froissart. In the first examples, the subject referent belongs to the sub-story of the feast given by the king to his guests in the Palais de la Cité:

(57) Menestreux estoient là à grant foison, qui ouvroient de leurs mestiers de ce que chascun savoit faire [Froissart 356]

ministrels were there in great abundance who worked of their professions of this that each knew do

'Minstrels were here in abundance, who carried out their professions in what each knew to do.'

The sentence-initial subject menestreux 'ministrels' is indefinite and introduces a new discourse referent. Notice that it would have been perfectly possible to begin the sentence with the place adverb là 'there' instead. In this position, a nominal expression such as menestreux, which establishes the aboutness topic for the subsequent portion of text, is probably focussed. Its placement is then best explained by the general observation that putting a constituent into sentence-initial position can be a means of marking focus on that constituent. 
The second example of a pre-verbal focussed subject occurs within the same sequence, when the author describes what he calls l'assise, viz. the layout of the guests around the tables:

(58) [...] et vous diray l'assise quelle elle fu. Pour la haulte table du roy l'evesque de Noion faisoit le chief et puis l'evesque de Lengres et puis de lez le roy l'archevesque de Rouen et puis le roy de France, qui [...] Aprés le roy ung petit en sus seoit la roynne de France [...] [Froissart 356]

and you tell-FUT.1SG the layout what it was for the high table of.the king the bishop of Noyon made the head and then the bishop of Langres and then of side the king the archbishop of Rouen and then the king of France who after the king un little in up sat the queen of France

(lit.) 'And I shall tell you the layout what it was. For the high table of the king the bishop of Noyon was at the top, and then the bishop of Langres and then nearby the king the archbishop of Rouen and then the king of France, who [...]. After the king, a little higher sat the queen of France.'

Here, the pre-verbal subject noun phrase l'evesque de Noion follows an adverbial phrase and contrasts with the last subject la roynne de France, which is in post-verbal position. The first subject, the first term in an enumeration, is arguably an identificational focus, which is not the case for the last subject.

The third examples of focussed pre-verbal nominal subjects is given in (59). Here Froissart depicts the events taking place at the Gate of Saint Denis: the royal cortege walks across a kind of shelter, decorated like a heaven full of angels which are represented by a children's choir. When the queen walks through the building, a little play is presented, during which some children dressed as angels put a crown on her head:

(59) Et ad ce que la roynne passa dedens sa littiere desoubz la porte le paradis s'ouvry et deux angles yssirent hors en eulx avalant et tenoient en leurs mains une tres riche couronne [...] Et la mirent et assirent les deux angles moult doulcement sur le chief de la roynne [...] [Froissart 351-352].

and to this that the queen passed inside the litter under the gate the heaven REFL opened and two angels went.out out in them descending and hold in their hands a very rich crown and her regarded and placed the two angels very gently on the head of the queen

'As the queen passed under the gate, inside her litter, the heaven opened and two angels came out and descended and held in their hands a very rich crown [...] And they placed it very gently on the head of the queen.'

The pre-verbal position of the first subject le paradis 'the heaven' seems to be correctly accounted for by the preceding explanation, since the referent has already been described in the preceding text passage. However, the second pre-verbal subject, the indefinite subject deux angles 'two angels', could have been been expected to surface in post-verbal position: while the children's choir dressed like angels has been depicted before, the two angels, as new protagonists, could be expected to receive focus. Now, the last sentence does not seem to be in accordance with what we said earlier: the subject is known, occurs inside a narrative sequence and yet it is post-verbal. But there is a feature which is of central importance here: the last subject is not a topic anymore, or at least not the principal topic, since the topic of that last sentence is the crown. Therefore, we must add the following constraint to the set of 
constraints already formulated: a pre-verbal subject that comes after triggering items must play a prominent topic role in the sentence.

All in all, we may propose the following hypothesis: A pre-verbal subject noun phrase represents a known, thematic discourse referent appearing inside and not at the beginning of a narrative sequence, and functioning as a protagonist of a sub-story with major thematic value. In some cases, such subjects are focussed and contrastive, which is compatible with the preceding conditions.

5.3 An example of the XSV constructions in the Journal d'un bourgeois de Paris: the paragraphs with item

In order to investigate the preceding hypothesis we examined sentences in our second reference text which are mainly used for introducing a new narrative sequence: those beginning with item. There are 147 sentences of this type in our corpus, and out of these 147 we found only 16 pre-verbal nominal subjects, a low percentage of little more than $10 \%$. In our statistics, the proportion of pre-verbal nominal subjects within the entire set of clauses is 381 out of 2080 , i.e., $18 \%$. Because nearly all narrative sequences begin with an independent clause, we also calculated the proportion of pre-verbal subjects within the set of all independent clauses: Here, the proportion is $213 / 1259=16.9 \%$, which is still high.

Thus, it seems that these sentences confirm the hypothesis proposed above. When we look at the 16 clauses in the Journal d'un bourgeois de Paris in which a nominal subject occurs preverbally, we notice that in several cases the sentence occurs inside a narrative or discursive chain, despite the item at the beginning. Example (5), repeated for convenience as (60) below, will serve to illustrate this point:

(60) Item, le jeudi ensuivant, ung autre nommé Colin de Brie, escuier, fut prins oudit lieu comme devant est dit, et prins au Palays, trayné comme Simonnet devant dit, et couppé sa teste es halles [...] [JBP §67]

item the Thursday following an other named Colinde Brie esquire was caught at.the.aforementioned place as afore is said and put in.the Palais dragged as Simonnet afore said and cut his head in.theHalles

'Next Thursday another man, called Colin de Brie, esquire, captured at the same place as above, was taken from the Palais, dragged to the Halles like Simon, and there beheaded.' (transl. Shirley 1968: 73)

The incident reported in (60) follows a similar episode which is brought back to mind, hence the indefinite un autre 'another one' is used. There are other similar cases. For instance, in the text passage immediately preceding the sentence in (61), the narrator has talked about the poor quality of wine, and he continues as follows:

(61) Item, ceulx de l'ost en avoient grant charté [...] [JBP §107]

item those of the army of.it had great cost

'They were very short of provisions in the army [...]' (transl. Shirley 1968: 89)

Something quite similar happens in a paragraph dealing with rising prices, where the sentence in (62) appears immediately after an analogous remark:

(62) Item, ung bien petit porc coustoit LX solz ou IIII frans [...] [JBP §176]

item a well small pig cost 60 sols or 4 francs

'A very small pig cost $60 s$. to four francs.' (transl. Shirley 1968: 107) 
Thus, many cases which at first seemed to be counter-examples to our hypothesis show a cutting up of sub-sequences, where pre-verbal subjects appear inside the whole sequence. A striking case involving the linkage of two paragraphs is visible in (63). Notice that the second paragraph is in fact the direct continuation of the story in the first sentence:

(63) Item, le moys d'aoust ensuivant, au commencement, aryva le roy d'Engleterre à toute sa puissance en Normendie, et print port emprès Harefleu, et assiegea Harefleu et les bonnes villes d'entour.

Item, monsieur de Guienne, filz ainsné du roy, se party de Paris le premier jour de septembre, à ung dimanche au soir, à trompes, et n'avoit que jeunes gens avec lui, et party pour aller contre les Angloys [...] [JBP §125-126]

item the month of August following at.the beginning arrived the king of England at all his force in Normandy and took harbour near Harfleur and besieged Harfleur and the good towns of around

item my.lord de Guienne eldest son of.the king REFL left of Paris the first day of September at a Sunday at.the evening at trumpets and NEG had but young people with him and left for go against the Englishmen.

'Early next August the King of England and all his forces arrived off the Norman coast. They landed at Harfleur and laid siege to Harfleur and the good towns near by. On a Sunday evening, September 1st, my lord of Guienne, the King's eldest son, left Paris to the sound of trumpets to go and fight the English. He took only young men with him.' (transl. Shirley 1968: 94)

Thus, even in this case of a new event with new protagonists occurring in a new paragraph, the difference in the position of the subject could be that the new event is to be seen as a continuation of what precedes. All things considered, there is only one case among the sixteen pre-verbal nominal subject clauses for which we have no explanation:

(64) Item, ce jeudi XIII jour de septembre, ung jeune homme osta la bande à l'ymage Sainct Huistace que on lui avoit baillée [...] Et tantost fut prins, fust tort ou droit, lui fut le poing coppé sur le pont Alleiz devant Sainct Huistace, et fut banny à touzjours mais; et si ne fust oncques homme qui osast dire le contraire, tant estoit tout mal gouverné et de maulvaises gens. [JBP §110]

item this Thursday 13th day of September a young man took.off the sash at the statue St. Eustace which one him-DAT had put and at.once was taken was.it wrong or right him-DAT was the fist struck.off on the bridge Alais in.front.of St. Eustace and was banished at always ever and indeed NEG was ever anybody who would.dare say the opposite so.much was everything evilly governed and by evil people

'On this Thursday, September 13th, a young man took off the sash which had been put on the statue of St. Eustace [...] Rightly or wrongly he was at once arrested and his fist was struck off on the Pont-Alais in front of St. Eustace's Church. Then he was banished for ever. Yet not one man dared oppose this, so evilly was everything governed, and by such evil men.' (transl. Shirley 1968: 90)

The episode related in (64) is isolated, and the indefinite subject is a new participant. The tenuous link with what precedes it could be that this story is told in order to illustrate the 
nastiness of the governing clan, the Armagnacs, as can be seen in the final remarks of this example.

\subsection{Generalization to narrative sequences}

We have tried to confirm the hypothesis of the relevance of the concept of narrative sequence by examining all the paragraphs of the reference edition of the Journal d'un bourgeois de Paris. There are 220 paragraphs in our labelled corpus, which divide the text in sequences of varying size. No independent narrative sequence begins inside a paragraph; on the other hand, some paragraphs continue a preceding one, as in (63) above. Out of the 220 paragraphs, 178 contain a subject, either a nominal or a pronominal one (if we put aside the beginnings which contain impersonal sentences, subject-less verbs, non-verbal expressions etc.). Within this set, there are 140 clauses with a post-verbal subject against 38 with a pre-verbal one. When we examine the context of the 38 clauses with pre-verbal subjects, we find that at least 17 are clearly linked to the preceding paragraph. A kind of discursive link is arguably also established in the three cases where the connector cependant 'however' appears; despite the fact that this connector introduces a new (sub-)story, it is used to make the new sentence contrast with the immediately preceding sequence. Therefore, only 18 out of 178 clauses with an overt subject remain in which a pre-verbal subject occurs at the beginning of a new narrative sequence. This rate (about $10 \%$ ) is very low and must be compared with the average rate of pre-verbal subjects in independent clauses, which is $46 \%$.

Among the 18 pre-verbal subjects that occur in clauses at the beginning of a new narrative sequence, there are some focussed topics. This is in accordance with the observations made above. We supposed (cf. section 1.2.8) that a position $\mathrm{C}$ for a focussed noun phrase remains available before the tensed verb even when other items are in the first position (in the preverbal sequence): this position could also be available for a subject noun phrase, whatever the structure may be in this case. ${ }^{11}$

In (65), for instance, we find a 'heavy' and informative subject at the beginning of a new discursive sequence, despite the presence of pre-verbal terms that could have triggered subject inversion:

(65) Item, environ la fin de novembre, l'an mil IIII ${ }^{C}$ et $X V$, le duc de Guienne, ainsné filx du roy de France, moult plain de sa voulenté plus que de raison acoucha malade et trespassa le XVIII jour de decembre oudit an, jour mercredi des IIII Temps. [JBP §132] item around the end of November the year thousand 400 and 15 the duke of Guienne eldest son of.the king of France much full of his will more than of reason laid.down sick and died the 18th day of

December of.the.said year day Wednesday of.the four time

'Towards the end of November 1415 the Duke of Guienne, the King's eldest son, rich in self-will, poor in wisdom, fell ill. He died on 18th December, the Wednesday in Ember week.' (transl. Shirley 1968: 97)

Such cases accord with previous observations: a pre-verbal focussed subject is always possible, even if it starts a new story, as is the case here.

\subsection{Pronominal subjects in independent clauses}

The hypothesis that there is a connection between the pre-verbal position of the subject and the discursive linking could explain the important statistical difference we found between ante-position and postposition of subject pronouns. When we compare the respective 
proportions of pre-verbal and post-verbal subjects in the two categories of nominal subjects (S) and subject pronouns (Sp) in the Journal d'un bourgeois de Paris, we find that these proportions differ considerably. As already mentioned above, our corpus contains 381 preverbal and 356 post-verbal subject noun phrases (in both independent and subordinate clauses), i.e., $51.6 \%$ of the nominal subjects occur in pre-verbal position. By contrast, no less than 331 out of the 347 pronominal subjects occur preverbally, i.e. 95.3\%. The reason for such a marked difference could be that most of the personal pronouns are third person anaphoric devices and thus are more readily found in discursive continuations rather than at the beginning of a narrative sequence. ${ }^{12}$

The situation for the impersonal subject item on is somewhat different. While its syntax is the same as that of the personal pronouns, pre-verbal position is not as highly favoured as with the other pronominal forms: there are 131 pre-verbal occurrences of on, compared to 37 post-verbal tokens. In independent clauses the ratio is similar to that of the subject noun phrases: 33 tokens are pre-verbal, and 36 post-verbal (cf. also the similar findings in Vance 1997: 189). This specific characteristic could be due to the primary meaning of on (it is not, strictly speaking, an anaphoric form). In the beginning of a narrative sequence, this item can thus be positioned after the verb, just like new subject noun phrases:

(66) Item, la premiere sepmaine de septembre ensuivant, fist on deffense aux bouchiers que plus ne vendissent leur char sur le pont Nostre-Dame [...] [JBP §150]

item the first week of September following made one prohibition to.the butchers that more NEG sell their meat on the bridge Notre Dame

'In the first week of September the butchers were forbidden to carry on their business any longer on the Pont Notre Dame [...]' (transl. Shirley 1968: 101-102)

However, on is never found in final position, which is a consequence of the cliticization process of that term, and it is never focussed either. The syntax of on is thus an additional argument for thesis that subjects in pre-verbal position establish a discourse link with what precedes.

\section{Pre-verbal object noun phrases in independent clauses}

An object noun phrase can precede the tensed verb, even if this is not very frequent, and this despite the potentially confusing order of the sentence (see 1.2 .4 above).$^{13}$ Such object noun phrases are always strongly focussed. As noted, they can occur in three different syntactic constructions in Middle French. However, most such OV constructions are subject-less, and it is difficult to determine where the subject would have been placed. The structural conditions of their occurrence are somewhat different from the verb second structures: they occur frequently in subordinate clauses, especially after the subject relative pronoun qui, and elsewhere when a subject pronoun is not realized. We found 20 occurrences of such OV structures in the Journal d'un bourgeois de Paris, among which 13 are in subordinate clauses. In relative clauses, especially after the subject relative pronoun qui, there are no semantic conditions for the object noun phrase to be pre-verbal. But in the seven cases of object-verb ordering in independent clauses, the object noun phrase is always an indefinite noun phrase, with a partitive meaning in six of these sentences, often with the indefinite determiner autre, cf. (67) and (68) (see also the examples in 1.2.4): 
(67) [...] que il commença à lermer fort des yeulx mais autre chose n'en osa faire pour paour d'esmouvoir le commun [...] [JBP §215]

that he began to weep strongly through.the eyes but other thing NEG of.it dared do for fear of arouse the common.people

'[...] indeed he wept bitterly, but that was all he could do about it for fear of arousing the people [...]' (transl. Shirley 1968: 124)

(68) [...] si se conseilla la justice, et du blé veoir voldrent, et ne virent point ou blé nulle deffaulte $[\ldots][\mathrm{JBP} \S 582]$

thus REFL considered the court and of.the corn see wanted and NEG-1

saw NEG-2 at.the corn no default

'The authorities considered the matter and decided to inspect the corn. They could see nothing wrong with it [...]' (transl. Shirley 1968: 267)

The explanation for such a placement of the object noun phrase before the verb must combine two different conditions. First, the object noun phrase must be strongly focussed (contrary to the subject noun phrase). Secondly, it must be linked to what precedes it, and this fits well with the semantic category of partitive noun phrases, since they introduce a subset of a previous discourse topic. Here too, then, the pre-verbal position could be more attractive for an item inside a narrative sequence.

\section{Conclusions}

As in Old French syntax, we need to distinguish between independent and subordinate clauses in the grammatical analysis of Middle French texts. In subordinate clauses, word order is not very different from that of Modern French, even if some OV constructions are found in Middle French that are impossible in the present-day language. In Middle French independent clauses, the majority of subject noun phrases is still placed after the verb. In XVS structures, we observed four structural types. There remains a verb second type, like in Old French, so long as it is borne in mind that the first position can be occupied by more than one single term. In such instances, the subject is a known topic. We suppose that Middle French has what we called an extended verb second structure, in which the subject is never the main focus of the clause and is followed by an argument noun phrase or a copula complement. Middle French also has the Stylistic Inversion type, mostly with a new, focussed subject. In the 'Heavy Inversion' type, the subject comes at the end of the clause, usually after adverbials, and is the major information focus in the sentence. Structural ambiguities are possible, and could explain reanalysis phenomena in such a period of competing grammars.

Not surprisingly, one can say that there is a gradation in focalization towards the end of the sentence, so that the item most focussed is normally the last one, followed only by possible additional comments. Thus, focussed, new subject noun phrases are often positioned at the very end of the sentence. Conversely, known, anaphoric, non-focussed post-verbal subjects appear, preferably, directly after the tensed verb.

Regarding the choice between pre-verbal and post-verbal subjects, we tried to determine which semantic features of the subject and its linkage to other constituents could possibly govern its position. The explanation offered in this study is linked to the narrative structure of the texts examined rather than to information structure at the sentence level. We hypothesized that in the beginning of a new narrative sequence the nominal subject, whether new or known, is preferably placed after the verb. Inside a narrative sequence, the subject (either previously introduced or presupposed in the context) is more likely to be in pre-verbal position if it 
remains a major topic of what is described in the sentence. The strong tendency to put such subjects occurring inside a narrative sequence in a pre-verbal position fits well with the properties of subject pronouns. Subject pronouns are seldom placed in a post-verbal position excepting generic on (due to the non-anaphoric meaning of that term). As in Old French, it is possible in Middle French to put a 'heavy' focussed subject in the pre-verbal sequence, independent from the narrative structure.

What remains in Middle French of non-subject noun phrases before the tensed verb seems to obey to a double constraint in independent clauses: such complement noun phrases are always strongly focussed, and they occupy the pre-verbal position for focussed constituents. They also belong to a peculiar class of noun phrases. Most of them are partitive noun phrases, referring to a wider set of entities and therefore show discourse linkage with previous information.

The results of this study demonstrate persuasively that communicative parameters must include narrative structuring in order to explain, at least partially, the observed variations in the Journal d'un bourgeois de Paris and in Froissart's Chroniques. However, future research must determine whether or to what extent the hypotheses and observations presented here can be generalized for other genres and texts of Middle French.

\section{Texts}

Anonymous. Journal d'un bourgeois de Paris. Ed. A. Tuetey 1881 \& ed. C. Beaune 1990 [Coll. Lettres gothiques]. [Years 1405-1418 (\$1-220) for the labelled corpus].

Froissart, J. 2004. Chroniques. Livre IV [Coll. Lettres gothiques], P. Ainsworth \& A. Varvaro (eds). Paris: Librairie générale française. [§1: Enthroning of the new queen of France, pp. 348-365].

Shirley, J. (ed.). 1968. A Parisian Journal 1405-1449. Translated from the anonymous Journal d'un Bourgeois de Paris. Oxford: Clarendon Press.

\section{References}

Buridant, C. 2000. Grammaire nouvelle de l'ancien français. Paris: Sedes.

Chafe, W.L. 1976. Givenness, contrastiveness, definiteness, subjects, topics, and point of view. In Subject and Topic, C.N. Li (ed.), 25-56. New York: Academic Press.

Chafe, W.L. 1994. Review of Firbas 1992. Language 70(2): 350-353.

Combettes, B. 2003. Variation dans la structure du syntagme verbal. In Évolution et variation en français préclassique. Études de syntaxe, B. Combettes (ed.), 171-210. Paris: Honoré Champion.

Cornish, F. 2001. L' 'inversion locative' en français, italien et anglais: propriétés syntaxiques, sémantiques et discursives. Cahiers de grammaire 26: 101-123.

Firbas, J. 1992. Functional Sentence Perspective in Written and Spoken Communication. Cambridge: Cambridge University Press.

Herman, J. 1990. Du latin aux langues romanes. Tübingen: Niemeyer.

Kayne, R.S. 1984. Connectedness and Binary Branching. Dordrecht: Foris.

Kayne, R.S. 1994. The Antisymmetry of Syntax. Cambridge MA: MIT Press.

É. Kiss, K. 1998. Identificational focus versus information focus. Language 74(2): 245-273.

Krifka, M. 2007. Basic notions of information structure. In The Notions of Information Structure [Interdisciplinary Studies on Information Structure 6], C. Féry, G. Fanselow \& M. Krifka (eds), 13-55. Potsdam: Universitätsverlag Potsdam.

Lemieux, M. \& Dupuis, F. 1995: The locus of verb movement in non-asymmetric verb second languages: the case of Middle French. In Clause Structure and Language Change [Oxford 
Studies in Comparative Syntax], A. Battye \& I. Roberts (eds), 80-109. Oxford: Oxford University Press.

Marchello-Nizia, C. 1987. La langue française aux XIVe et XVe siècles. Paris: Nathan.

Marchello-Nizia, C. 1995. L'évolution du français. Ordre des mots, démonstratifs, accent tonique. Paris: Armand Colin.

Price, G. 1961. Aspects de l'ordre des mots dans les Chroniques de Froissart. Zeitschrift für romanische Philologie 77(1): 15-48.

Skårup, P. 1975. Les premières zones de la proposition en ancien français. Essai de syntaxe de position [Revue Romane. Numéro special 6]. Copenhagen: Akademisk Forlag.

Vance, B.S. 1997. Syntactic Change in Medieval French: Verb-second and Null Subjects [Studies in Natural Language and Linguistic Theory 41]. Dordrecht: Kluwer.

Wehr, B. 2007. Syntaxe et pragmatique: marquage du topique en ancien français. In Actes du XXIVe Congrès International de Linguistique et de Philologie Romanes, D. Trotter (ed.), vol. 3, 477-501. Tübingen: Niemeyer. 


\section{Appendix}

\section{Encoding of subjects: statistics}

\section{JBP: 2080 clausal cells (tensed V).}

$737 \mathrm{~S}$ (subject noun phrases)

347 subject personal pronouns +168 on $=515$ of personal pronoun type

Number of subject pronouns: 515 personal pronouns $+267 q u i+19$ other subject relative pronouns Total: $515+286=801$ subject pronouns $(\mathrm{s})$.

Total of realized subjects: $\mathrm{S}+\mathrm{s}=737+801=1538$.

Subjectless V: $2080-1538=542(25 \%$ of all clauses $)$.

Position: pre-verbal S:

Insertions:

SV: $368, \mathrm{SxV}: 13(3.4 \%)$

pre-verbal personal pronouns pre-verbal on :

Total $\mathrm{S}+\mathrm{s}$ (without relative pronouns):

pre-verbal subjects:
381 post-verbal S:

356

VS: 222 VxS: $134(37.6 \%)$

331 post-verbal personal pronouns: 16

131 post-verbal on: 37

843 post-verbal subjects: $\quad 409$ (32.6\%).

\section{Distribution in independent and subordinate clauses:}

Independent clauses:

pre-verbal S:

pre-verbal pers. pronouns:

pre-verbal on:

Total: pre-verbal subjects:

Subordinate clauses:

pre-verbal S:

pre-verbal personal pronouns: pre-verbal on:

Total (without relative pronouns): pre-verbal subjects
213 post-verbal S:

81 post-verbal personal pronouns: 16

33 post-verbal on: 36

327 post-verbal subjects: $391(54 \%)$.

168 post-verbal S: $\quad 17$

250 post-verbal personal pronouns: 0

98 post-verbal on:

516 post-verbal subjects:

\section{Froissart (Livre IV, \$1): 488 clausal cells.}

208 subject noun phrases.

62 subject personal pronouns +26 on $=88$ subjects of personal pronoun type.

Number of subject pronouns: 88 subject pronouns of personal $+72 q u i+11$ other subject relative pronouns $=$ Total: 171 subject pronouns.

Total of realized subjects: $\mathrm{S}+\mathrm{s}=208+171=379$.

Subjectless verbs: $488-379=109(22.3 \%$ of all clauses $)$.

Position: pre-verbal S:

96 post-verbal S :

Insertions: SV: $90 \mathrm{SxV}: 6(5.5 \%)$

VS: $80 \quad$ VxS: $32(28.5 \%)$

pre-verbal personal pronouns: 54

pre-verbal on:

25

):

175 post-verbal subjects:

post-verbal personal pronouns: 8

post-verbal on:

$121(40.8 \%$ of all subjects $)$.

Distribution in independent and subordinate clauses:

Independent clauses: pre-verbal S: post-verbal S: 
pre-verbal personal pronouns: 24 pre-verbal on:

Total: pre-verbal subjects 82

Subordinate clauses: pre-verbal S: pre-verbal personal pronouns: 30 pre-verbal on:

Total (without relative pronouns) pre-verbal subjects: post-verbal pers. pronouns: 7

post-verbal on: $\quad 0$

post-verbal subjects: $\quad 15$ (58\% of all subjects).

post-verbal S: $\quad 4$

post-verbal personal pronouns: 1

post-verbal on:

1

post-verbal subjects: $\quad 6(6 \%$ of all subjects $)$.

1 For a general evaluation, see Marchello-Nizia (1997: chap. 24).

2 Discussing Old French, Wehr (2007) makes use of pragmatic and communicative notions by studying dislocated phrases. Vance (1997) also links structural positions and information (see, for example, her section 3.5.4).

3 Historical chronicles are probably less likely to employ rhetorical or literary devices.

4 Each finite clause has a tensed verb; participles and infinitives are analysed as complements of tensed verbs. Verbless clauses are excluded from analysis here, since the attribution of functional labels like subject can be pointless in these cases.

5 In complex inversion structures of Modern French, it is now often supposed that V does not raise to $\mathrm{C}$ (see for example Kayne 1994: 44).

6 Generally, X in the formula XSV is limited to triggers other than noun phrases, i.e., connectives and adverbials. Only very rarely is a non-subject noun phrase immediately followed by a subject. When this occurs, it is probably the case that the non-subject noun phrase is in extraposition.

7 According to Herman, subject inversion after é (et) 'and' is the exception rather than the rule in Old French (Herman 1990: 274, speaking about the first extended text in prose of Old French, Les quatre livres des rois).

8 The triggers of subject inversion are underlined.

9 Thus, Price (1961) gives the percentage of $54.2 \%$ of pre-verbal subjects in independent clauses for the extract of Froissart analysed; but he includes subject pronouns, which have quite a different proportion of pre-verbal subjects. Quite surprisingly, Herman in his study of Les quatre livres des rois (1990: 262) states that he did not take into account clauses with a compound tense and passive clasuses. However the statistics in Vance (1997: 350) confirm the predominance of the inverted order with subject noun phrases.

10 According to Marchello-Nizia (1997: 415), the subject-verb ordering in independent clauses is predominant in a proportion varying between $52 \%$ and $75 \%$. I did not find the same percentages in the, admittedly limited, corpus that I have analysed. It is also quite probable that the percentage of SV grew over the years. Notice that Marchello-Nizia's values are given for the whole period of Middle French.

11 It could be a continuation of the topicalized position of the verb second type. Vance (1997: 341) imagines two different strategies for topicalization in Middle French, where topicalized elements either move into the specifier of CP (as in verb second languages) or into an adjoined position.

12 The same difference was noted by Herman (1990: 280) for Old French. His explanation is in line with what I am saying here: according to Herman, the use of a personal pronoun made it possible to begin a sentence with a stressed term without thereby laying emphasis on this initial term (recall that the subject pronoun was not yet a clitic in Old French), a term which was related to discourse referents already given in the context or the situation.

13 Object-verb orderings continue to be attested throughout the sixteenth century. Combettes (2003: 175) cites sentences of this type, for example Ceste methode a bien sceu pratiquer le sage Socrates, lit. 'That method could well practice the wise Socrates' (Thévet, Les Singularitez de la France antarctique, 1558). The position of the complement is dependent on a preceding context. 